\title{
Small Mammals in Modified Pinyon-Juniper Woodlands, New Mexico
}

\author{
KIETH E. SEVERSON
}

\section{Abstract}

The effects of pinyon (Pinus edulis)-juniper (Juniperus spp.) treatments on rodent abundance, 13 to 18 years after treatment, were studied in southwestern New Mexico from 1981 to 1983. Treatments included bulldozing, bulldozing/piling/burning, thinning, and untreated woodland. The area had not been grazed by livestock since time of treatment but was subjected to light and irregular use by wild ungulates. Total rodent numbers were significantly greater $(P \geqq 0.05)$ on all treated areas compared to untreated woodlands but individual species and groups responded differently. Woodrats (Neotoma spp.) and brush mice (Peromyscus boylii) increased in abundance as slash accumulations increased, regardless of condition of overstory. Pinyon mice $(P$. truei) and rock mice ( $P$. difficilus) numbers were also greater where slash was present, but only if the pinyon-juniper overstory was relatively intact. Grassland rodents, as a group, were more abundant on areas where the pinyon-juniper overstory and slash had been removed (bulldozed and bulldozed/piled/burned), but reduced numbers on bulldozed plots where slash was left suggested slash accumulations may have detrimental effects on numbers of these species. Treatments did not influence number of different rodent species. Data indicate that numbers of individuals and proportions of rodent species can be affected by manipulation of pinyonjuniper overstory and method of slash disposal.

Pinyon-juniper (Pinus edulis-Juniperus spp.) woodlands occupy $20.5 \%$ and $18.0 \%$ of the land surface in Arizona and New Mexico, respectively (Short 1979). Mechanical methods such as chaining and bulldozing have been used to control large tracts of these woodlands (Springfield 1976) and generally have resulted in increased herbage production, but effects on wildlife habitats have been variable (Severson and Medina 1983).

Studies on effects of pinyon-juniper treatments on small mammals include the following: cottontails (Sylvilagus audubonit) (Kundaeli and Reynolds 1972) and white-throated woodrats (Neotoma albigula) (Turkowski and Watkins 1976) in New Mexico, and several species of small mammals in Utah (Baker and Frischknecht 1973, Smith and Urness 1984); Colorado (O'Meara et al. 1981); and Arizona (Turkowski and Reynolds 1970, Kruse et al. 1979). Most were conducted on areas grazed by livestock, and time intervals between treatment and study dates varied from l (Turkowski and Watkins 1976) to 25 years (Kruse et al. 1979).

The objective of this study was to test the hypotheses that there were no differences in number of rodent species, total individuals, and number of individuals of selected species and species groups on untreated pinyon-juniper woodland compared to woodlands subjected to mechanical control practices 13 to 18 years after treatment.

\section{Study Area and Methods}

The study was conducted on the Fort Bayard Allotment, Gila National Forest, $16 \mathrm{~km}$ east of Silver City, New Mexico. Important trees and shrubs include pinyon, one-seed juniper (Juniperus monosperma), alligator juniper (J. deppeana), gray oak (Quercus

\footnotetext{
Author is research wildlife biologist, USDA Forest Service, Rocky Mountain Forest and Range Experiment Station. Research was conducted at the Station's Research Work Unit in Tempe, Ariz, in cooperation with Arizona State University. Station headquarters is in Fort Collins, Colo.

Author would like to thank personnel of the Gila National Forest and the New Mexico Game and Fish Department for their assistance throughout the study and Dr. Bruce Hayward, Western New Mexico University, for identifying and weighing specimens. Special thanks are extended to Mary Gilbert and Gary Helbing for their assistance with collections.

Manuscript accepted 30 April 1985.
}

grisea), and haury mountainmahogany (Cercocarpus breviflorus). More than 30 grass species occur on the allotment but two-thirds of the perennial grass production is from blue grama (Bouteloua gracilis) and sideoats grama ( $B$. curtipendula). Over 50 species of forbs have been identified, but no single species is dominant. Common forb genera include globemallow (Sphaeralcea spp.), goosefoot (Chenopodium spp.), and buckwheat (Eriogonum spp.) (Kundaeli and Reynolds 1972).

Upland soils are primarily Lithic and Lithic Vertic Haplustolls while Aquic Haplustolls are common in lowland areas (Unpulished data, A.L. Medina, Rocky Mountain Forest and Range Experimental Station, Tempe, Ariz.).

Elevation ranges from 1,806 to $2,070 \mathrm{~m}$. Annual precipitation averages $393 \mathrm{~mm}, 55 \%$ of which falls as rain from July through September. Annual precipitation for 1981,1982 , and 1983 was 427 , 332 , and $454 \mathrm{~mm}$, respectively. Mean annual temperature is 12.8 ${ }^{\circ} \mathrm{C}$, with mean monthly extremes of $3.5^{\circ} \mathrm{C}$ (January) and $22.6^{\circ} \mathrm{C}$ (July). Weather records are from Fort Bayard State Hospital on the southern edge of the study area.

The Allotment is part of the Fort Bayard military reservation which was established in 1869 . Yearlong, excessive use by livestock resulted in deteriorated range conditions in 1937 when all livestock, except for a few pack and saddle animals, were removed (Reynolds 1964). The pinyon-juniper control treatments described in the following paragraph were established as part of a mule deer (Odocoileus hemionus) and elk (Cervus elaphus) habitat study. The areas used in the rodent study described herein have not been grazed by livestock since the treatments were applied. The military reservation, however, is within the range of 90 to $120 \mathrm{elk}$, about 100 mule deer, and about 75 white-tailed deer (Odocoileus virginianus). The area used for this study was approximately $10 \%$ of the entire reservation and use by wild ungulates was probably proportional.

Pinyon-juniper treatments were randomly established in each of 2 blocks. The lower block, at an elevation of 1,880 to $1,935 \mathrm{~m}$, was treated in 1965 and the upper block, 1,935 to $2,040 \mathrm{~m}$, in 1970 . Treatments included (1) thinning (pinyon and junipers were cut to a minimum spacing of $6.1 \mathrm{~m}$ and left in place); (2) bulldozing (all pinyon and junipers were pushed over with a bulldozer and left in place); (3) bulldozing/piling/burning (trees were pushed and piled with a bulldozer, then burned); and (4) undisturbed woodland. All treated plots were approximately 120 ha.

During September 1981, each plot was divided into 6 sampling areas and a set of 2 transects was randomly placed in each. Each transect consisted of 17 trapping locations spaced $10 \mathrm{~m}$ apart. Each location consisted of 2 traps, a standard rat trap, and a museum special. Trapping was conducted during the second and third weeks of September each year. Traps were baited with a mixture of peanut buttcr, oatmeal, and an ant repellent, dimethylpthalate (Anderson and Ohmart 1977). Traps were run in one transect within each plot segment in 1981, the other in 1982, and the first transect again in 1983. Because of the time required to check and bait traps only 3 transects were run within each treatment for 4 consecutive days; then the traps were moved to 3 other transects and run for the next 4 consecutive days. Traps were left open for 24-hour trap sessions and were checked daily. Each of the 8 treatment areas received 816 trap-days effort per year. Captured individuals were tagged, placed in plastic bags, and frozen; then identified and weighed as time permitted.

Rodent data were analyzed with 3-factor analyses of variance (blocks, years, and treatments) with 6 observations per cell. Each 
observation represented the total number of individuals captured on 1 transect in 1 year. Mean separation was by Newman-Keuls test (Zar 1984). All species could not be analyzed separately because of small sample sizes, so tests included the following species or species groups: (1) white-throated woodrat; (2) all woodrats, white-throated woodrat plus Stephens woodrat $(N$. stephensi), Mexican woodrat ( $N$. mexicana), and a few specimens that could only be identified as woodrats; (3) brush mouse (Peromyscus boylii); (4) other woodland species, pinyon mouse ( $P$. truei), and rock mouse ( $P$. difficilis); (5) grassland species, which included white-footed mouse ( $P$. leucopus), southern grasshopper mouse (Onychomys torridus), western harvest mouse (Reithrodontomys megalotis), and Ord's kangaroo rat (Dipodomys ordii); and (6) total individuals, which included all of the above. The null hypotheses tested was that there were no differences in number of species or number of individuals of each species (or species group) trapped among treatments. All statistical inferences were made at 0.05 probability level.

Densities of trees and shrubs were estimated by counting the number of individuals on 5- by $25-\mathrm{m}$ sampling areas. Stein's twostage test (Steel and Torrie 1980) was used to determine the number of sampling areas per treatment, which varied from 25 to 55 . Percentage slash cover was estimated by counting meters of slash intercept on twelve, $30-\mathrm{m}$ transects, randomly located on rodent trapping transects in each treatment.

Plant and animal nomenclature follow Nickerson et al. (1976) and Hall (1981), respectively.

\section{Results and Discussion}

\section{Vegetative Changes}

Densities of pinyon and junipers were lowest on bulldozed/piled/burned and bulldozed treatments (Table 1). Pinyon has been reestablishing on all treated areas at a slightly faster rate than the junipers. Densities of broad-leaved shrub species tended to be greater under well-developed tree overstories.

Table 1. Densities of trees and shrubs (no./ha) and slash cover (\%) in 4 pinyon-juniper treatments at Fort Bayard, New Mexico. Numbers are means \pm standard errors.

\begin{tabular}{|c|c|c|c|c|}
\hline Tree/shrub & $\begin{array}{l}\text { Untreated } \\
\text { woodland }\end{array}$ & $\begin{array}{c}\text { Bulldozed/ } \\
\text { piled/ } \\
\text { burned }\end{array}$ & Bulldozed & Thinned \\
\hline & \multicolumn{4}{|c|}{-Density (number/ha) } \\
\hline Junipers & $107 \pm 13$ & $10 \pm 3$ & $35 \pm 10$ & $142 \pm 19$ \\
\hline Pinyon & $252 \pm 32$ & $42 \pm 8$ & $39 \pm 7$ & $522 \pm 71$ \\
\hline Gray oak & $385 \pm 44$ & $156 \pm 17$ & $209 \pm 24$ & $222 \pm 33$ \\
\hline Hairy mountain- & & & & \\
\hline mahogany & $235 \pm 29$ & $80 \pm 14$ & $154 \pm 25$ & $206 \pm 30$ \\
\hline Other & $\underline{214 \pm 28}$ & $66 \pm 14$ & $111 \pm 18$ & $53 \pm 12$ \\
\hline \multirow[t]{2}{*}{ Totals } & $1,193 \pm 83$ & $354 \pm 34$ & $548 \pm 43$ & $1,145 \pm 107$ \\
\hline & $3 \pm 1$ & -Co & $\%)-\overline{13 \pm 2}$ & \\
\hline
\end{tabular}

Slash accumulations were 2.5 to 3 times greater on the thinned and bulldozed plots than on untreated woodlands (Table 1). Most slash on untreated plots resulted from natural mortality. Intermediate accumulations on bulldozed/piled/burned areas resulted from incomplete burning of piled slash and trees or shrubs that were pushed over and crushed but not piled.

\section{Small Mammal Diversity}

Thirteen rodent species were trapped over the 3-year period and the number of species caught was similar among treatments. Ten rodent species were found on all treatments (Table 2). Two additional species, deer mouse (Peromyscus maniculatus) and silky pocket mouse (Perognathus flavus), were trapped in the bulldozed/piled/burned treatment but only 1 individual of each species was caught. An additional species found on the thinned treatment, cliff chipmunk (Eutamias dorsalis), was represented by 2 individuals.

Results of previous studies have been varied. Turkowski and Reynolds (1970), working in Arizona, reported more rodent species where pinyons and junipers had been bulldozed 3 to 7 years prior to sampling than on untreated areas. Conversely, $O^{\prime} M e a r a$ et al. (1981) showed species diversity to bc greater in untreated pinyon-juniper woodlands than on chained areas sampled 1,8 , and 15 years after treatment in Colorado. Variable results among studies and differences of only 1 to 3 minor species, each represented by few individuals, between treated and untreated areas indicate that pinyon-juniper control has minimal effects on number of rodent species.

\section{Number of Individuals}

Significantly higher total numbers of individuals were trapped on treated than on untreated woodlands (Table 2), but there were no differences in total individuals among the areas subjected to pinyon-juniper control practices.

Significantly more white-throated woodrats and total woodrats were trapped on bulldozed and thinned areas than on untreated woodlands. Intermediate numbers occurred on bulldozed/piled/burned areas. Brush mice were significantly more numerous on the bulldozed and thinned treatments and less numerous on the bulldozed/piled/burned and untreated plots (Table 2). Slash appears an important habitat component for these species. Generally, highest numbers of woodrats and brush mice were found in treatments with high slash accumulations, i.e., bulldozed and thinned (Table 1). Intermediate number were found in treatments with intermediate amounts of slash (bulldozed/piled/burned) and fewest in treatments with least slash (untreated woodlands).

The addition of slash to the woodland character of the thinned plot accounted for the significantly greater number of woodland species (pinyon mice and rock mice) on the thinned as compared to untreated woodlands. The pinyon-juniper overstory was apparently more critical because these woodland species were least abundant on treatments where this overstory was removed (bulldozed and bulldozed/piled/burned areas) even if slash was present (Table 2).

Other investigators have also noted a preference for slash cover by rodents, particulary deer mice, voles (Microtus spp.) (Baker and Frischknecht 1973), and woodrats (Turkowski and Reynolds 1970, Turkowski and Watkins 1976). O'Meara et al. (1981) noted significantly more slash on areas chained 1 to 15 years previously compared to untreated sites, but attributed increases in deer mice, least chipmunks (Eutamias minimus), and plains pocket mice (Perognathus flavescens) on treated areas to increases in shrubs and perennial grasses. Slash may be especially important to woodrats because cover near the ground is important for shelter-site selection (Olsen 1973). Slash not only provides such cover but also furnishes the building materials (bark, pieces of wood, etc.) for shelter construction (Turkowski and Watkins 1976).

Not all species responded to the presence of slash, however. Grassland rodents (white-footed mice, southern grasshopper mice, western harvest mice, and Ord's kangaroo rats) were significantly more abundant on the bulldozed/piled/ burned treatment, indicating a preference for open stands of gray oak and hairy mountainmahogany. Reduced numbers on bulldozed plots indicate slash accumulations may have a detrimental effect on most of these species. Treatments leaving a pinyon-juniper overstory (untreated and thinned plots) had significantly fewer total individuals of this group (Table 2).

While grass and forb growth was not measured during trapping, Short et al. (1977), working on the same study areas, found total herbage production was greater $(P<0.05)$ on bulldozed and bulldozed/piled/burned areas than on thinned and untreated wood- 
Table 2. Total numbers of individuals of each rodent species and species group trapped on four pinyon-juniper treatments during 1981, 1982, and 1983 at Fort Bayard, New Mexico.

\begin{tabular}{|c|c|c|c|c|}
\hline Rodent & $\begin{array}{l}\text { Untreated } \\
\text { woodland }\end{array}$ & $\begin{array}{l}\text { Bulldozed/ } \\
\text { piled/ } \\
\text { burned }\end{array}$ & Bulldozed & Thinned \\
\hline $\begin{array}{l}\text { Stephen's woodrat } \\
\text { Mexican woodrat } \\
\text { White-throated woodrat }\end{array}$ & $\begin{array}{c}9 \\
2 \\
117 \mathrm{a}^{\prime} \\
\end{array}$ & $\begin{array}{c}2 \\
4 \\
156 \mathrm{ab} \\
\end{array}$ & $\begin{array}{r}15 \\
6 \\
205 b \\
\end{array}$ & $\begin{array}{c}26 \\
12 \\
183 \mathrm{~b} \\
\end{array}$ \\
\hline All woodrats ${ }^{2}$ & $\overline{129} \mathrm{a}$ & $\overline{168 a b}$ & $\overline{229 b}$ & $\overline{222 b}$ \\
\hline Brush mouse & $45 a$ & $57 a$ & $98 b$ & $115 b$ \\
\hline $\begin{array}{l}\text { Pinyon mouse } \\
\text { Rock mouse }\end{array}$ & $\begin{array}{r}24 \\
2\end{array}$ & $\begin{array}{l}1 \\
5\end{array}$ & $\begin{array}{l}4 \\
7\end{array}$ & $\begin{array}{l}48 \\
10\end{array}$ \\
\hline All woodland mice & $26 a$ & $6 b$ & $\mathbf{1 1 b}$ & $58 \mathrm{c}$ \\
\hline $\begin{array}{l}\text { White-footed mouse } \\
\text { Southern grasshopper mouse } \\
\text { Ord's kangaroo rat } \\
\text { Western harvest mouse }\end{array}$ & $\begin{array}{r}9 \\
13 \\
16 \\
8 \\
\end{array}$ & $\begin{array}{l}50 \\
66 \\
31 \\
28 \\
\end{array}$ & $\begin{array}{r}9 \\
30 \\
10 \\
46 \\
\end{array}$ & $\begin{array}{r}14 \\
3 \\
11 \\
7\end{array}$ \\
\hline Total grassland species & $46 a$ & $175 \mathrm{c}$ & $95 b$ & $35 a$ \\
\hline Total Individuals ${ }^{3}$ & $246 a$ & $408 b$ & $433 b$ & $432 b$ \\
\hline
\end{tabular}

IValues within a row followed by same letter are not significantly different at the 0.05 probability level.

Includes unidentified woodrats.

Includes deer mice, silky pocket mice, and cliff chipmunks

lands. No differences were found between the two cleared treatments or between thinned and untreated areas. Relative differences in herbage production were still apparent at time of trapping and may have contributed to increased numbers of grassland species and decreased numbers of woodland species (Table 2).

The only significant block differences were the number of whitethroated woodrats and total woodrats which were most numerous in the lower block and brush mice which were more abundant in the upper block. In the case of woodrats, Turkowski and Watkins (1976), working in the same study area, found more woodrat houses in the lower block than in the upper block prior to any treatments. These results, therefore, have been interpreted to be due to differences in elevation and related environmental factors rather than age of treatment.

Results from this study cannot be compared directly to those where livestock grazing was occuring on study plots. While use by wild ungulates had occurred since treatments were imposed, effects were likely small because such use was light and irregular. Any large ungulate has the potential to alter food and cover used by rodents, however. Black and Frischknecht (1971) noted differences in species composition of rodents when comparing ungrazed range with ranges that were heavily or moderately grazed by cattle. Sheep grazing on big sagebrush (Artemisia tridentata) ranges caused significant reductions in both diversity and density of small mammals, but only diversity was reduced on areas dominated by crested wheatgrass (Agropyron cristatum) (Reynolds and Trost 1980). No information is available relating livestock to slash reduction. It is probable, however, that large ungulates, particularly cattle, elk, and horses, could cause reductions in slash over a period of years through rubbing and trampling activities.

\section{Conclusions and Management Implications}

Controlling pinyon and juniper trees by bulldozing, bulldozing piling/burning, and thinning did not affect rodent species diversity but did result in increased numbers of individuals of several species and groups. Managers may have the option of influencing which species increase the most by manipulating slash. Treatments leav- ing slash, for example, yielded highest numbers of woodrats and brush mice regardless of whether the pinyon-juniper canopy was completely removed. Pinyon and rock mice, collectively, also responded favorably to slash accumulations but only if the pinyonjuniper canopy was relatively intact (e.g., thinned treatment). Grassland species, including white-footed mice, southern grasshopper mice, western harvest mice, and Ord's kangaroo rats, were most abundant where the pinyon-juniper overstory was removed and the slash piled and burned.

The study area had not been grazed by livestock since treatments were applied but has received light and sporadic use by deer and elk. Livestock likely influence rodent populations by altering food and cover; slash may even be affected by larger ungulates through rubbing and trampling activities. The degree of influence on rodent numbers depends on intensity and duration of livestock grazing. While caution should certainly be used in extending these results to areas that are grazed by livestock, there is no existing information that covers these interactions. One purpose of this study was to provide management with a series of options developed under a "no grazing" regime which can be used as a foundation for comparing results from similar studies where livestock grazing was present and defined.

\section{Literature Cited}

Anderson, B.W., and R.D. Ohmart. 1977. Rodent bait additive which repels insects. J. Mamm. 58:242.

Baker, M.F., and N.C. Frischknecht. 1973. Small mammals increase on recently cleared and seeded juniper rangeland. J. Range Manage. 26:101-103.

Black, H.L., and N.C. Frischknecht. 1971. Relative abundance of mice on seeded sagebrush-grass range in relation to grazing, USDA Forest Serv. Res. Note INT-147.

Hall, E.R. 1981. The mammals of North America. Vols. I and II. John Wiley and Sons, New York, N.Y.

Kruse, W.H., R.P. Balda, M.J. Simono, A.M. Macrander, and C.D. Johnson. 1979. Community development in two adjacent pinyon-juniper eradication areas twenty-five years after treatment. J. Environ. Manage. 8:237-247. 
Kundaeli, J.N., and H.G. Reynolds. 1972. Desert cottontail use of natural and modified pinyon-juniper woodland. J. Range Manage. 25:116-118.

Nickerson, M.F., G.E. Brink, and C. Feddema. 1976. Principal range plants of the central and southern Rocky Mountains: Names and symbols. USDA Forest Serv. Gen. Tech. Rep. RM-20.

Olsen, R.W. 1973. Shelter-site selection in the white-throated woodrat, Neotoma albigula. J. Mamm. 54:594-610.

O'Meara, T.E., J.B. Haufler, L.H. Stelter, and J.G. Nagy. 1981. Nongame wildlife responses to chaining of pinyon-juniper woodland. J. Wild!. Manage. 45:381-389.

Reynolds, H.G. 1964. Elk and deer habitat use of a pinyon-juniper woodland in southern New Mexico. Trans. N. Amer. Wildl. and Natur. Resour. Conf. 29:438-444.

Reynolds, T.D., and C.H. Trost. 1980. The response of native vertebrate populations to crested wheatgrass planting and grazing by sheep. $\mathbf{J}$. Range Manage. 33:122-125.

Severson, K.E., and A.L. Medina. 1983. Deer and elk habitat management in the Southwest. J. Range Manage. Monogr. No. 2.
Short, H.L. 1979. Deer in Arizona and New Mexico: Their ecology and a theory explaining recent population decreases. USDA Forest Serv. Gen. Tech. Rep. RM-70.

Short, H.L., W. Evans, and E.L. Boeker. 1977. The use of natural and modified pinyon-juniper woodlands by deer and elk. J. Wildl. Manage. 41:543-559.

Smith, C.B., and P.J. Urness. 1984. Small mammal abunda nce on native and improved foothill ranges. Utah. J. Range Manage. 37:353-357.

Springfield, H.W. 1976. Characteristics and management of the southwestern pinyon-juniper ranges: the status-of-our-knowledge. USDA Forest Serv. Res. Pap. RM-160.

Steel, R.G.D., and J.H. Torrie. 1980. Principles and procedures of statistics: A biometrical approach. McGraw-Hill Book Co.. New York.

Turkowski, F.J., and H.G. Reynolds. 1970. Response of some rodent populations to pinyon-juniper reductions on the Kaibab Plateau, Arizona. Southwest. Natur. 15:23-27.

Turkowski, F.J., and R.K. Watkins. 1976. White-throated woodrat ( NeOtoma albigula) habitat relations in modified pinyon-juniper woodland of southwestern New Mexico. J. Mamm. 57:586-59l.

Zar, J.R. 1984. Biostatistical analysis. 2nd ed. Prentice-Hall, Inc., Englewood Cliffs, N.J. 